\title{
Моделі конструювання соціальної згуртованості: теоретичні рефлексії та емпіричні кейси
}

\author{
Олександра Дейнеко - \\ канд. сои. наук, дочент \\ кафедри соиіології, Харківський \\ національний університет \\ ім. В. Н. Каразіна, Украӥна \\ Oleksandra Deineko - \\ PhD in Sociology, Associate \\ Professor of Department of \\ Sociology, V. N. Karazin Kharkiv \\ National University, Ukraine \\ E-mail: deineko@karazin.ua \\ ORCID: https://orcid.org/0000- \\ 0002-3659-0861
}

DOI: $10.29038 / 2306-3971-2021-$ 01-33-40

Received: May, 2021

$1^{\text {st }}$ Revision: May, 2021

Accepted: June, 2021
У статті розроблено моделі конструювання соціальної згуртованості на мезосоціальному рівні в межах академічного підходу до концептуалізації цього феномену. Аналізуючи недоліки наявних спроб типологізації соціальної згуртованості, пропонуємо власну класифікацію моделей конструювання цього феномену, в основу якої покладено різні «стрижні гуртування». Класифікація представлена термінальною згуртованістю (формула: довкола чогось/когось), простою інструментальною згуртованістю у вигляді позитивно інструментальної й негативно інструментальної (задля чогось/когось та проти чогось/когось) і складною інструментальною згуртованістю, що грунтується на синтезі попередніх формул (проти чогось/когось задля чогось/когось і задля чогось/когось проти чогось/ когось). Наведені моделі соціальної згуртованості запропоновано розглядати як згуртованість у дії, тобто в актуалізованому стані, виокремлюючи, окрім того, стан «нульової згуртованості» як згуртованості на папері. Підсумовано, що формули конструювання соціальної згуртованості $\epsilon$ взаємопов'язаними та внутрішньо динамічними, що можуть змінювати одна одну. Наголошено на необхідності розмежування соціального капіталу й соціальної згуртованості, ототожнення яких у межах академічних досліджень призводить до появи псевдозгуртованості.

Ключові слова: соціальна згуртованість, моделі конструювання, термінальна згуртованість, інструментальна згуртованість, згуртованість у дії, згуртованість на папері.

Deineko Oleksandra. Models of Social Cohesion Construction: Theoretical Reflections and Empirical Cases. The paper is dedicated to developing models of social cohesion construction on the mesosocial level in the context of academic approach in studying this phenomenon. Basing on analysis of weaknesses of existing attempts to typologize social cohesion (made by O. Yarskaya-Smirnova and A. Green and J. Janmaat), the author offers his own classification of models for constructing this phenomenon, which is based on various "cores of cohesion", nominated as social cohesion formula. Author's classification is presented by terminal cohesion (based on formula: around something/someone), simple instrumental cohesion in the form of positively instrumental and negatively instrumental (respectively: for something/someone and against something/someone) and complex instrumental cohesion based on the synthesis of previous formula (against something/someone for something/someone and for something/someone against something/someone). It is proposed to consider the above models of social cohesion as cohesion-in-action or the actualized state of social cohesion, distinguishing also the state of «zero cohesion» as cohesion-on-paper. It is concluded that formula for social cohesion constructing are interrelated and internally dynamic, that makes possible to mix them and change each other. Emphasis is placed on the necessity to distinguish social capital and social cohesion, basing on author's presumption that social capital (as a special type of social relations) does not necessary lead to social cohesion construction (as well as social community formation does not guarantee social cohesion presence in contrast to social capital existence). It is highlighted that theoretical equating of social capital and social cohesion in the framework of academic research poses the existence of pseudo-cohesion.

Key words: social cohesion, models of construction, terminal cohesion, instrumental cohesion, cohesion-inaction, cohesion-on-paper. 


\section{ПОСТАНОВКА ПРОБЛЕМИ}

В епоху цифрового індивідуалізму складно недооцінити значущість феномену соціальної згуртованості як властивості різноманітних соціальних спільнот та систем ${ }^{1}$ (держав, суспільств, груп, об'єднань тощо), що дає змогу ефективно мобілізувати зусилля різних соціальних суб'єктів у розв'язанні внутрішніх конфліктів та реагуванні на зовнішні виклики чи загрози. Водночас, будучи категорією західного академічного дискурсу (Bernard, 1999; Jenson, 2011) та конструктом соціальної політики (Council of Europe, 2004) вже понад 20 років, концепт соціальної згуртованості досі залишається поза увагою українських соціологів.

Із метою впорядкування підходів до вивчення феномену соціальної згуртованості у світовому науковому дискурсі сформувалося два дослідницьких табори - академічний, представники якого розглядають соціальну згуртованість як, передусім, наукову категорію (Chan, To, Chan, 2006; Bottoni, 2018); і політичний, прихильники котрого концептуалізують соціальну згуртованість як категорію соціальної політики (Jenson, 2011; Berger-Schmitt, 2002; Jeannotte, 2003). Залежно від особливостей дефінування соціальної згуртованості дослідники тяжіють або до концепції соціального капіталу, що, на їхнє переконання, покладено в ії основу, або до теоретичного фрейму соціальної солідарності, слідуючи дюркгейміанським традиціям. Розмаїття підходів до визначення соціальної згуртованості дійсно вражає: вона постає як антонім конфлікту, властивість суспільства, ступінь стабільності, ознака міцності зв'язків, приналежність до спільноти, ознака групи, напрям політики (Fonseca, Lukosch, Brazier, 2019). Не є усталеним у науковому дискурсі також погляд на ціннісні засади згуртованого суспільства: думки варіюються від концепцій ціннісної гомогенності до ціннісної гетерогенності (Schiefer, Noll, 2017). У західних наукових студіях соціальну згуртованість найчастіше розглядають як феномен макросоціального рівня (Chan, To, Chan, 2006; Bottoni, 2018; Social Cohesion Radar..., 2013) та навіть мегасоціального (Delhey, et al., 2018), проте спроби iï дослідження на рівні окремих соціальних груп чи спільнот (тобто на мезорівні) є менш поширеними (Rajulton, Ravanera, Beaujot, 2007; Kearns, Forrest, 2000). Відсутність національних наукових традицій дослідження соціальної згуртованості, багаторівнева природа цього феномену, а також одночасність використання в політичному, повсякденному та академічному дискурсах сприяє формуванню теоретичної й методологічної невизначеності. Усе це актуалізує пошук та оформлення концептуального підгрунтя задля визначення способів конструювання й відтворення соціальної згуртованості на різних соціальних рівнях. Спробою такого пошуку може стати розроблення моделей конструювання соціальної згуртованості.

\section{1. АНАЛІЗ ОСТАННІХ ДОСЛІДЖЕНЬ ТА ПУБЛІКАЦІЙ. ФОРМУЛЮВАННЯ МЕТИ}

Поряд із численними кейсами емпіричного вимірювання соціальної згуртованості (Chan, To, Chan, 2006; Bottoni, 2018; Social Cohesion Radar..., 2013) здійснення спроб теоретичної концептуалізації цього феномену є менш поширеною дослідницькою стратегію. Для нашого дослідження науковий інтерес представляють роботи О. Ярської-Смирнової й В. Ярської (2014) та Е. Гріна й Дж. Джанмаата (Green, Janmaat, 2011). Спираючись на роботи класиків соціологічної думки та сучасні закордонні дослідження, О. Ярська-Смирнова концептуалізує різні контексти виникнення соціальної згуртованості, у яких остання постає як «соціальне закриття у відповідь на загрозу», «ресурс влади», «взаємна вигода», «ресурс взаєморозуміння», «рівність та інклюзія». Водночас недоліками наведеної концептуалізації вважаємо: 1) відсутність критерію, що покладений в основу класифікації; 2) змішування академічного й політичного підходів (соціальна згуртованість як «рівність та інклюзія» $є$ конструктом політичного дискурсу); 3) відсутність перевірки цієї моделі на iii «повноту» (наприклад, згуртованість може формуватись і як відповідь на ексклюзію, тобто в

\footnotetext{
${ }^{1}$ У цій роботі разом із поняттям «соціальна спільнота» ми використовуємо дефініцію «соціальна система», послуговуючись іï концептуалізацією в рамках теорії структурації Е. Гідденса: «Соціальні системи як відтворювані соціальні практики, володіють не структурами, а структуральними властивостями, а структура як зразок соціальних відносин, що існує в певний час і в певному просторі, проявляється завдяки практикам, які пам'ять фіксує як напрям поведінки компетентних суб'єктів діяльності» (Гидденс, 2005, с. 59).
} 
діалектиці інклюзії-ексклюзії) і недостатність емпіричних кейсів для ілюстрації тих чи інших механізмів; 4) відсутність концептуального визначення статусу цих проявів соціальної згуртованості (чи то як контекстів, дискурсів, формул, моделей).

Грунтуючись на позиціях методологічного партикуляризму, Е. Грін та Дж. Джанмаат визнають «вбудованість» соціальної згуртованості в історичний, політичний, соціальний i культурний контексти та запроваджують категорію «режимів ${ }^{1}$ соціальної згуртованості» - сукупності соціальних відносин, що конституюють певний тип соціальної згуртованості (Green, Janmaat, 2011). У своїй роботі вони виокремлюють три режими: а) ліберальний (з акцентом на активності громадського суспільства, толерантності, прийнятті різноманіття й відсутності іншого набору спільних цінностей); б) республіканський르 (примат держави у формуванні згуртованості, інститути якої забезпечують добробут і соціальний захист; значущість спільних цінностей, відчуття приналежності та інституційної довіри); в) соціал-демократичний (схожий із республіканським, але з більшим акцентом на рівності й соціальному партнерстві). Незважаючи на наявність спільного критерію для виокремлення режимів соціальної згуртованості, бачимо, що їх «внутрішня» характеристика позбавлена системного підходу у визначенні набору індикаторів. До того ж ця типологія виконана в рамках політичного підходу, що певним способом обмежує ії використання в академічному дискурсі. Незважаючи на такий «політичний перекіс», дефініція соціальної згуртованості, запропонована дослідниками, представляє науковий інтерес: вона постає як «властивість, за допомогою якої суспільства та індивіди є пов'язаними завдяки дї спеціальних установок, поведінки, правил та інститутів, що спираються більшою мірою на консенсус, аніж на примус» (Green, Janmaat, 2011, p. 28). Загалом, узявши за основу наведене визначення соціальної згуртованості, додамо, що ця «властивість» $€$ властивістю соціального порядку, який конституюється й відтворюється відповідними практиками соціальних суб'єктів. Відтак мета дослідження - розробка моделей конструювання соціальної згуртованості в рамках академічного підходу. Незважаючи на те, що більшість закордонних науковців використовує схожі емпіричні моделі вимірювання соціальної згуртованості на соцієтальному та мезосоціальному рівнях (наприклад Chan, To, Chan, 2006; Rajulton, Ravanera, Beaujot, 2007), у межах цієї роботи ми ілюструватимемо моделі конструювання соціальної згуртованості на прикладі різних видів мікро- й мезосоціальних спільнот.

\section{2. ВИКЛАД ОСНОВНОГО МАТЕРІАЛУ ТА ДИСКУСІЯ}

Як ми вже зазначили вище, недоліками окремих спроб типологізації соціальної згуртованості $є$ відсутність визначення критеріїв, що покладені в основу класифікації, логічної перевірки запропонованої типології на «достатність», а також неврахування ймовірного взаємозв'язку чи внутрішньої динаміки між визначеними (класами чи видами). Розроблені нами моделі конструювання соціальної згуртованості покликані уникнути таких недоліків. По-перше, ми чітко визначаємо, що в межах цієї класифікації акцентуємо увагу саме на особливостях конструювання соціальної згуртованості як динамічної сутності, що діалектично постає і як процес, і як продукт соціального конструювання. По-друге, критерієм нашої типології $є$ «стрижень гуртування», що $\epsilon$ своєрідною формулою соціального конструювання згуртованості. По-третє, нами здійснена логічна перевірка запропонованої типології на іiї «достатність» (хоча, звісно ж, ми не претендуємо на абсолютизм такої достатності). По-четверте, окрему увагу приділяємо аналізу ймовірного взаємозв'язку та внутрішнього динамізму виділених моделей.

Перша модель конструювання соціальної згуртованості представлена формулою згуртованість «довкола чогось/когось», що передбачає появу «термінальної згуртованості». У межах цієї моделі стрижнем конструювання соціальної згуртованості постає певна спільна соціальна цінність/цінності (ідея, ідеологія, практика, знання, інтерес тощо), що публічно артикулюється й поділяється представниками певної спільноти. Цінність (цінності) інтеоріоризується на індивідуальному рівні та сприяє активізації відповідних соціальних практик членами спільноти в межах інституційних норм,

\footnotetext{
${ }^{1}$ І з доцільністю використання поняття «режим» варто посперечатись, оскільки далі дослідники аналізують більшою мірою змістовні якості згуртованості, пї специфіку, аніж певні формальні ознаки, що більш влучно розкриває поняття «режим».

2 Який у подальшому дослідники номінують як режим соціального ринку (social market regime).
} 
що, зі свого боку, відтворює соціальну згуртованість як властивість соціальної системи. Така формула соціальної згуртованості покладена в основу функціонування сімейної згуртованості, де набір спільних цінностей є, зазвичай, доволі широким (від любові до дітей до пошанування сімейних традицій), що відображаються в множинності спільних практик (спільне дозвілля, святкування, переживання складних моментів тощо). У цьому зв'язку сім'я виступає майже ідеальним типом термінальної згуртованості, що має міцне ціннісне підгрунтя, тісні емоційні зв’язки, а взаємодії між iii членами здійснюються на засадах реципрокності (взаємодопомоги, взаємопідтримки тощо). За схожими сценаріями відбувається конструювання соціальної згуртованості в різноманітних спільнотах за інтересами - творчих гуртках чи спортивних секціях, що об'єднують любителів шахів, садівництва чи поезії. Спільні цінності можуть відсилати до більш широких культурних традицій, культурних форм (згуртованість етнічних груп).

Водночас для певних соціальних спільнот спільна цінність, що покладена в основу об'єднання, може трансформуватися чи доповнюватися появою спільної мети (наприклад, любителі волейболу починають брати участь у змаганнях). Такий стан справ відсилає нас до другої формули конструювання згуртованості «задля чогось/когось», на підставі чого виникає «позитивно інструментальна згуртованість", для якої стрижнем гуртування виступає категорія спільного блага, що досягається в результаті групових взаємодій. Емпіричними прикладами такого типу згуртованості є студентська група, що виконує групове проєктне завдання; спортивна команда, учасники якої беруть участь у змаганнях; трудовий колектив, що працює на досягнення спільної мети (як-от підвищення заробітної плати); об’єднані територіальні громади, створені з метою підвищення рівня якості життя їхніх мешканців (докладніше див. (Deineko, 2021)). У цьому контексті важливо наголосити саме на спільному характері мети, що веде до спільного блага, оскільки навіть взаємна мета взаємодій, що покладена в основу появи соціального капіталу', може не призводити до виникнення феномену соціальної згуртованості (наприклад, взаємодії продавця й покупця чи інтеракції в трудовому колективі, учасники якого взаємодіють не на умовах кооперації, а на конкурентних засадах).

На відміну від «термінальної згуртованості» «позитивно інструментальна згуртованість»є менш «вибагливою» щодо різноманітних «спільностей»: так, учасником любительської спортивної команди з волейболу може стати людина будь-якого віку, статі, національності рівня матеріальних статків чи інших стратифікаційних ознак, а головним критерієм входження в цю соціальну спільноту стане наявність відповідних спортивних навичок. Така широка пропускна спроможність не $\epsilon$ можливою для входження в родинну спільноту, що передбачає більш системний селективний відбір 2 . Тому конструювання соціальної згуртованості за формулою «задля чогось/когось» більшою мірою тяжіє до сприйняття різноманіття. Водночас саме це робить цю модель конструювання соціальної згуртованості менш надійною та крихкою, оскільки після досягнення спільної мети спільноти можуть припиняти свою діяльність (спортивна команда, що виграла завдання) чи позбавлятися інституційних умов свого існування (студентська група, що завершила навчання в 3ВО). На відміну від перманентності й глибинності термінальної згуртованості, позитивно інструментальна згуртованість є більш темпоральною та ситуативною.

В основу іншої форми інструментальної згуртованості покладено формулу конструювання «проти чогось/когось», що відтворює «негативно інструментальну згуртованість» (у термінології О. Ярської-Смирнової «закриття у відповідь на загрозу»). Ця модель заснована на дії певних групових механізмів, ідентифікованих ще класиком соціології Г. Зіммелем. Доречно згадати, що німецький соціолог пов'язує ступінь гостроти конфлікту із силою внутрішньої згуртованості груп, що конфліктують: чим гостріший конфлікт, тим сильніше він внутрішньо консолідує ці групи (Зиммель, 1996). У межах нашого дослідження має йтися не стільки про обов’язкову залученість у

1 За Р. Патнемом, соціальний капітал - «особливості соціальної організації, такі як мережі, норми та довіра, що сприяють координації та співпраці задля взаємної вигоди» (Putnam, 1993, p. 36).

${ }^{2}$ Цей висновок дає нам змогу критично осмислити позиціонування соціальної згуртованості «як рівності та інклюзії», за О. Ярською-Смирновою, підкреслюючи той факт, що інклюзія не $є$ проявом згуртованості, вона $\epsilon$ властивістю соціальних систем (спільнот), яким притаманні різні моделі соціальної згуртованості (отже, і різне співвідношення «інклюзії-ексклюзії)). 
конфлікти, скільки про наявність спільної зовнішньої загрози, що усвідомлюється представниками певної спільноти (образ «спільного ворога», за Г. Зіммелем). Наприклад, новина про скорочення заробітної плати працівникам трудового колективу може сприяти активізації їхніх спільних взаємодій із метою опозиції такій ідеї (ініціювання діалогу з керівництвом, підготовка офіційного звернення тощо), що, зі свого боку, перетворюватиме цю групу з класу в собі у клас для себе спільноту, що спроможна захищати інтереси своїх членів. Ця формула може виникати як на етапі існування вже сформованої спільноти (трудовий колектив, студентська група, спортивна команда), так і бути стрижнем їі створення (як приклад, різноманітні контркультурні рухи, ідея створення яких фактично реалізує формулу протистояння зовнішньому світові). До того ж ця формула проявляється не лише інтернально щодо певної спільноти, але й екстернально, формуючи певний відклик на рівні інших групи чи спільнот. Крізь призму такого підходу можна поглянути на події Революції гідності, коли побиття студентів-учасників громадської акції (що було сприйнято як спільну зовнішню загрозу з боку держави щодо громадянського суспільства) завдяки активізації механізмів солідарності та реціпрокності на рівні інших суб'єктів громадянського суспільства призвело до масових публічних акцій протесту як діяльнісного прояву соціального гуртування.

Водночас соціальна спільнота може бути не лише «реципієнтом» (жертвою) зовнішнього виклику, але й суб'єктом, що його формує, щодо ставлення до інших соціальних спільнот. У цьому зв'язку для аналізу конфліктних взаємодій можна запропонувати виокремлення самостійного підвиду негативно інструментальної згуртованості - екстернально деструктивну згуртованість, що властива спільнотам, які об'єднують зусилля задля знищення соціальної згуртованості інших спільнот (цей різновид соціальної згуртованості може бути детальніше досліджений у межах аналізу міжгрупових конфліктів, війн тощо).

Окремим варіантом синтезу позитивно та негативно інструментальної згуртованості виступає складна інструментальна згуртованість, що конструюється на основі двох «дзеркальних» формул: «проти чогось-когось задля чогось/когось» та «задля чогось/когось проти чогось/когось». Ця модель одночасно заснована на механізмах двох попередніх кейсів. На відміну від негативно інструментальної згуртованості, метою групування в межах формули «проти чогось-когось задля чогось/когось» виступає не стільки необхідність відповіді на зовнішній виклик, скільки системна робота 3 відтворення попереднього соціального порядку. Ілюстраціями втілення такої формули $€$ множинні громадські акції, що виникли в Україні як відповідь на зовнішню екзистенційну загрозу світову пандемію навесні 2020 року («Підвези лікаря», «STOP COVID-19», «Вірус позитивного мислення» тощо). Наприклад, акція «Підвези лікаря» активізувала об'єднання зусиль українців задля нормалізації діяльності системи охорони здоров'я в Україні в період локдауну. Імовірно, що проведення таких акцій не призвело до формування стійких і визначених соціальних спільнот, але це сприяло посиленню соціальної згуртованості на соцієтальному рівні, оскільки більшість закордонних дослідників цього феномену розглядають практики громадського активізму як один із ключових емпіричних індикаторів соціологічного вимірювання соціальної згуртованості (Chan, To, Chan, 2006; Bottoni, 2018). Інший приклад реалізації цієї комбінованої формули конструювання соціальної згуртованості - це відомий кейс Гліба Кузнєцова - студента на інвалідному візку, котрий навчався в одному з російських ЗВО. У мережі Інтернет можна знайти відео, на якому одногрупники Гліба підіймають його на руках на другий поверх ЗВО через відсутність відповідної інфраструктури та свідоме ігнорування особливих освітніх потреб Гліба з боку адміністративно-викладацького корпусу (докладніше випадок описаний у (Ярская-Смирнова, Ярская, 2014). Медійне висвітлення цього випадку сприяло суттєвим змінам на рівні інклюзивної політики даного ЗВО (тобто досягнуто перевизначення соціального порядку щодо нівелювання «загрози»).

Прикладом реалізації формули конструювання згуртованості «задля чогось/когось проти чогось/когось» є підхід, використаний українським законодавцем у межах Державної стратегії регіонального розвитку України до 2027 року ${ }^{1}$ Стратегічною ціллю державної регіональної політики до 2027 р. в цьому документі визначено «формування згуртованої держави в соціальному, гума-

${ }^{1}$ Державна стратегія регіонального розвитку на 2021-2027 роки: Постанова КМУ від від 5 серп. 2020 р. № 695. Отримано 01.06.2021 з https://zakon.rada.gov.ua/laws/show/695-2020-\%D0\%BF\#Text. 
нітарному, економічному, екологічному, безпековому та просторовому вимірах», що спрямована на посилення інтеграції регіональних просторів у загальноукраїнський (задля чогось) в умовах загрози зовнішньої військової агресії (проти чогось).

Чотири наведені формули конструювання соціальної згуртованості характеризують пї актуалізований стан (здуртованість у діï). Згадаємо, що цей феномен діалектично пов'язує процес i результат, тому має більше різноманіття станів. Соціальна згуртованість може не бути властива соціальним групам чи спільнотам в актуалізованому стані, проте їі появу можуть «запустити» ті чи інші соціальні механізми. Тому різновидом станів соціальної згуртованості пропонуємо виділяти «нульову або потенційну згуртованість» (зууртованість на папері), що на певних етапах існування соціальних спільнот може бути відсутньою чи існувати в зародковому стані (наприклад, спільнота мешканців багатоквартирного будинку, що в подальшому може зіткнутися зі спільними викликами чи об'єднатися спільною метою).

Від такого стану соціальної згуртованості варто, на нашу думку, відокремлювати «псевдоздуртованість», поява якої обумовлена помилковим ототожненням змісту понять соціальної згуртованості та соціального капіталу в роботах деяких дослідників цього феномену. Зокрема, М. МакКрекен розуміє під останньою «характеристику суспільства, щзо визначає зв'язки й відносини між соціальними суб'єктами, такими як індивіди, групи, асоціації, територіальні одиниці〉 (MacCracken, 1998, p. 3), фактично ототожнюючи згуртованість і соціальний капітал. Інший напрям дефінування присутній у позиції Світового банку, який визначає соціальний капітал «не просто як суму інститутів суспільства, а як клей, що утримує їх разом» (Beauvais, Jenson, 2002, p. 25). Проте такі варіанти визначення видаються нам украй обмеженими, оскільки вони не враховують, що наявність зв'язків чи відносин, які засновані на взаємній меті (тобто обміні) (соціальний капітал), а не на спільності цінностей, цілей чи викликів не гарантують появу соціальної згуртованості. Наприклад, кейс взаємодій із виконання замовлення постійному клієнту (що передбачає для соціальних суб'єктів - клієнта та виробника - взаємне благо, гроші взамін на товар чи послугу) може бути досліджений крізь оптику феномену соціального капіталу, проте цей кейс не формує стрижнів для гуртування. На відміну від нульової згуртованості, псевдозгуртованість не може перейти в актуалізований стан без зміни сутнісних умов взаємодій.

\section{ДОСЛІДНИЦЬКІ ВИСНОВКИ}

Наведені формули конструювання соціальної згуртованості не є відокремленими та статичними, вони можуть поєднуватися чи змінювати одна іншу: клуб за інтересами може сформувати мету участі у творчому конкурсі чи відчути на собі зовнішні виклики; студенти, котрі працюють над виконанням командного завдання, можуть бути пов’язані не лише орієнтацією на отримання спільного блага у вигляді оцінки, але й спільною цінністю знань і захопленням навчальним предметом. Важливу роль у конструюванні соціальної згуртованості відіграють не лише соціальні суб'єкти, що відтворюють ії в практичній площині різних типів соціальних дій (ціле раціонально, традиційно чи ціннісно раціонально за М. Вебером), але й соціальні структури, що нормативно об'єктивують згуртованість (задаючи різні нормативні паттерни взаємодій - кооперація чи конкуренція, індивідуальна чи проєктна робота, нормативні засади для консенсусу чи примусу тощо).

Цілком очевидно, що запропоновані моделі конструювання соціальної згуртованості не позбавлені логічних та концептуальних недоліків, серед яких - імовірно, обмежено універсальний характер їх застосування; прирівнювання нерівного (кардинальна різниця між сутністю термінальної й інструментальної типів згуртованості); теоретичне редукування та обмежена перевірка на достатність тощо. Водночас аналітична ідентифікація наведених моделей дала нам змогу суттєво розширити перспективні площини соціологічної концептуалізації соціальної згуртованості, серед яких: 1) можливість буття соціальної згуртованості у двох станах - актуалізованому (згуртованість у діiі) та потенційному (згуртованість на папері); 2) різна пропускна спроможність соціальних систем у діалектичній площині «спільне/різноманітне» у конструюванні згуртованості (менша «вибагливість» формул інструментальної згуртованості щодо різних «спільностей» та тяжіння до сприйняття різноманіття). У практичній площині цей висновок засвідчує актуальність конструювання моделей 
інструментальної згуртованості на міжсистемному рівні (поєднуючи різні спільноти чи соціальні системи). Ілюстративним у цьому зв'язку є визначення соціальної згуртованості, наведене в документах Ради Європи: соціальна згуртованість - «спроможність суспільства забезпечувати добробут усіх своїх членів, мінімізуючи розбіжності (диспропориіі) та уникаючи маргіналізації. Згуртоване суспільство - це спільнота вільних людей, які здатні до взаємної підтримки й переслідують спільні иілі демократичними засобами» (Council of Europe, 2004, p. 3); 3) концептуальна хибність ототожнення соціального капіталу й соціальної згуртованості, коли взаємність вигод не формує спільності благ (як прототипи ринкового та неринкового, що не можуть бути ототожнені), і значущість подальшого теоретичного розмежування цих понять; 4) необхідність диференціації ступенів стійкості соціальних спільнот (та соціальних систем), у яких превалюють різні моделі соціальної згуртованості (термінальна забезпечує більшу надійність та стійкість, інструментальна більш крихка та ситуативна); 5) актуальність застосування контекстуального аналізу феномену соціальної згуртованості, що враховує не лише внутрішні соціальні зв'язки, але й зовнішні зв'язки між різними соціальними спільнотами.

\section{ДЖЕРЕЛА ТА ЛІТЕРАТУРА}

Гидденс Э. (2005). Устроение общества: очерк теории структурации. Москва: Академический проект.

Зиммель, Г. (1996). Избранное. Созериание жизни. Москва: Юрист.

Ярская-Смирнова, Е. Р., Ярская, В. Н. (2014). Социальная сплоченность: направления теоретической дискуссии и перспективы социальной политики. Получено 28.05.2021 c http://www.jourssa.ru/sites/all/files/volumes/2014_4/Iarskaya_Yarskaya_2014_4.pdf

Beauvais, C., Jenson, J. (2002). Social Cohesion: Updating the State of the Research. Ottawa: Canadian Policy Research Networks.

Berger-Schmitt, R. (2002). Considering social cohesion in quality of life assessments: Concept and measurement. Social Indicators Research, 58, 403-428. doi.org/10.1007/0-306-47513-8_18

Bernard, P. (1999). Social cohesion: A dialectical critique of a quasi-concept. Lien social et Politiques, 41, 47-59.

Bottoni, G. A. (2018). Multilevel Measurement Model of Social Cohesion. Social Indicators Research, 136 (3), $835-$ 857. doi.org/10.1007/s11205-016-1470-7

Chan, J., To, H. and Chan, E. (2006). Reconsidering social cohesion: Developing a definition and analytical framework for empirical research. Social indicators research, 75(2), 273-302. doi.org/10.1007/s11205-005-2118-1

Council of Europe (2004). Revised Strategy for Social Cohesion. European Committee for Social Cohesion, Strasbourg.

Deineko, O.O. (2021). Social Cohesion in Decentralized Ukraine: From Old Practices to New Order. Studia Socjologiczne, 1 (240), 117-138. doi.org/10.24425/sts.2021.136281

Delhey, J., Boehnke, K., Dragolov, G., Zsófia, S Ignácz, Larsen M., Lorenz J. and Koch M. (2018). Social cohesion and its correlates: A comparison of Western and Asian societies. Comparative Sociology, 17 (3-4), 426-455. doi.org/10.1163/15691330-12341468

Fonseca, X., Lukosch, S., Brazier, F. (2019). Social Cohesion Revisited: a New Definition and How to Characterize It. Innovation: The European Journal of Social Science Research. 32 (2), 231-253. doi.org/10.1080/13511610. 2018.1497480

Green, A., Janmaat, J. (2011). Regimes of social cohesion: societies and the crisis of globalization. Palgrave Macmillan: Basingstoke.

Jeannotte, M. Sharon (2003). Social cohesion: Insights from Canadian research. Retrieved May 26, 2021 from https://www.researchgate.net/publication/228981786_Social_cohesion_Insights_from_Canadian_research.

Jenson, Jane (2011). Defining and measuring social cohesion. Commonwealth Secretariat: UNRISD.

Kearns, A., Forrest, R. (2000). Social Cohesion and Multilevel Urban Governance. Urban Studies, 37 (5-6), 995-1017. doi.org/10.1080/00420980050011208

MacCracken, M. (1998). Social cohesion and macroeconomic performance. Retrieved May 23, 2021 from http://citeseerx.ist.psu.edu/viewdoc/download?doi=10.1.1.469.9884\&rep=rep1\&type=pdf.

Schiefer, D. and Noll, J. van der. (2017). The Essentials of Social Cohesion: A Literature Review. Social Indicators Research. 132, 579-603. doi.org/10.1007/s11205-016-1314-5

Putnam, R. (1993). Making Democracy Work. Civic Tradition in Modern Italy. Princeton: Princeton University Press.

Rajulton, F., Ravanera, Z. R. and Beaujot, R. (2007). Measuring social cohesion: An experiment using the Canadian national survey of giving, volunteering, and participating. Social Indicators Research, 80(3), 461-492. doi.org/10.1007/s11205-006-0011-1 
Social Cohesion Radar: Measuring Common Ground. An International Comparison of Social Cohesion Methods Report. Retrieved May 01, 2021 from http://aei.pitt.edu/74134/1/Social_cohesion_radar.pdf

\section{REFERENCES}

Beauvais, C., Jenson, J. (2002). Social Cohesion: Updating the State of the Research. Ottawa: Canadian Policy Research Networks.

Berger-Schmitt, R. (2002). Considering social cohesion in quality of life assessments: Concept and measurement. Social Indicators Research, 58, 403-428. doi.org/10.1007/0-306-47513-8_18

Bernard, P. (1999). Social cohesion: A dialectical critique of a quasi-concept. Lien social et Politiques, 41, 47-59. doi.org/10.7202/005057ar

Bottoni, G. A. (2018). Multilevel Measurement Model of Social Cohesion. Social Indicators Research, 136 (3), $835-$ 857. doi.org/10.1007/s11205-016-1470-7

Chan, J., To, H. and Chan, E. (2006). Reconsidering social cohesion: Developing a definition and analytical framework for empirical research. Social indicators research, 75(2), 273-302. doi.org/10.1007/s11205-005-2118-1

Council of Europe (2004). Revised Strategy for Social Cohesion. European Committee for Social Cohesion, Strasbourg.

Deineko, O.O. (2021). Social Cohesion in Decentralized Ukraine: From Old Practices to New Order. Studia Socjologiczne, 1 (240), 117-138. doi.org/10.24425/sts.2021.136281

Delhey, J., Boehnke, K., Dragolov, G., Zsófia, S Ignácz, Larsen M., Lorenz J. and Koch M. (2018). Social cohesion and its correlates: A comparison of Western and Asian societies. Comparative Sociology, 17 (3-4), 426-455. doi.org/10.1163/15691330-12341468

Fonseca, X., Lukosch, S., Brazier, F. (2019). Social Cohesion Revisited: a New Definition and How to Characterize It. Innovation: The European Journal of Social Science Research. 32 (2), 231-253. doi.org/10.1080/13511610. 2018.1497480

Giddens A. (1984). The Constitution Of Society: Outline of the Theory of Structuration. Cambridge: Polity Press.

Green, A., Janmaat, J. (2011). Regimes of social cohesion: societies and the crisis of globalization. Palgrave Macmillan: Basingstoke.

Iarskaia-Smirnova E. R., Yarskaya V. N. (2014). Social Cohesion: Directions of Theoretical Discussion and Perspectives for Social Policy. Retrieved May 28, 2021 from http://www.jourssa.ru/sites/all/files/volumes/ 2014_4/Iarskaya_Yarskaya_2014_4.pdf

Jeannotte, M. Sharon (2003). Social cohesion: Insights from Canadian research. Retrieved May 26, 2021 from https://www.researchgate.net/publication/228981786_Social_cohesion_Insights_from_Canadian_research

Jenson, Jane (2011). Defining and measuring social cohesion. Commonwealth Secretariat: UNRISD.

Kearns, A., Forrest, R. (2000). Social Cohesion and Multilevel Urban Governance. Urban Studies, 37 (5-6), 995-1017. doi.org/10.1080/00420980050011208

MacCracken, M. (1998). Social cohesion and macroeconomic performance. Retrieved May 23, 2021 from http://citeseerx.ist.psu.edu/viewdoc/download?doi=10.1.1.469.9884\&rep=rep1\&type=pdf

Schiefer, D. and Noll, J. van der. (2017). The Essentials of Social Cohesion: A Literature Review. Social Indicators Research. 132, 579-603. doi.org/10.1007/s11205-016-1314-5

Simmel, G. (1996). «Favorites. Contemplation of life». Moscow: Jurist.

Putnam, R. (1993). Making Democracy Work. Civic Tradition in Modern Italy. Princeton: Princeton University Press.

Rajulton, F., Ravanera, Z. R. and Beaujot, R. (2007). Measuring social cohesion: An experiment using the Canadian national survey of giving, volunteering, and participating. Social Indicators Research, 80(3), 461-492. doi.org/10.1007/s11205-006-0011-1

Social Cohesion Radar: Measuring Common Ground. An International Comparison of Social Cohesion Methods Report. Retrieved May 01, 2021 from http://aei.pitt.edu/74134/1/Social_cohesion_radar.pdf 